\title{
Associations Between Armillaria Species and Host Plants in U.K. Gardens
}

\author{
Jassy Drakulic, ${ }^{\dagger}$ Caroline Gorton, Ana Perez-Sierra, Gerard Clover, and Liz Beal, Royal Horticultural Society, Department of Plant \\ Health, RHS Wisley, Woking, Surrey, GU23 6QB, U.K.
}

\begin{abstract}
Honey fungus (Armillaria spp.) root rot is the disease most frequently inquired about by U.K. gardeners to the Royal Horticultural Society. Armillaria epidemiology has been studied within forestry and agriculture, but data are lacking within gardens, which have greater host plant diversity than orchards and vineyards and greater disturbance than woodlands. Which Armillaria species are responsible for garden disease, and how the broad range of susceptible ornamentals are differentially affected is not known. To address this, isolates of Armillaria were obtained from dead and dying plants from across the U.K. over a 4-year period (2004 to 2007). Species

were identified by PCR-RFLP for IGS, and further verified by speciesspecific PCR for EF-1 $\alpha$. Of the seven species known in the U.K., three were identified: A. mellea (83.1\%), A. gallica (15.8\%), and A. ostoyae (1.1\%). Armillaria was isolated from trees, shrubs, and nonwoody plants including bulbs and vegetables, with newly recorded hosts listed herein. A. mellea was associated with infections of multiple hosts, and with all infections of the most common host, Ligustrum. In sites where more than one Armillaria species was found, the combination was of A. mellea and A. gallica, raising questions regarding the interactions of these species in U.K. gardens.
\end{abstract}

The Armillaria genus of basidiomycete fungi, known commonly as honey fungus, contains a variety of species that reside within the soil growing either as saprotrophs or necrotrophs on living or dead plant material. It has been the most common disease identified by pathologists at the Royal Horticultural Society (RHS) advisory service for more than 20 years. For the period 2001 to $2016,17.8 \%$ of all disease infections identified by the RHS were Armillaria. The presence of the fungus in gardens is frequently reported to the RHS because of the distinct disease symptoms, which include butt rot and root rot, with dieback and poor above-ground growth as a consequence of subterranean symptoms. Visible morphological features of the disease comprise rhizomorphs in the soil or over bark surfaces, white mycelial fans underneath the bark, plus the appearance of honey-colored fruiting bodies in the autumn.

There are six species of Armillaria usually reported in the U.K., a figure derived from sampling of woodland sites (Gregory 1989; Rishbeth 1982), although a seventh has also been reported in a small number of cases (Jefferies 1999; Pérez-Sierra 2004). This genus can infect plant roots and stem-bases, causing disease in many host genera, particularly in trees and shrubs. The inoculum can persist in the soil or on fragments of decaying infected plant material even after removal of infected plants, and thus the choice of replacement is important to prevent the new plants from succumbing to disease after a short time (Smith and Kile 1981).

While trees are well known to host these fungi, shrubs and hedges, plus herbaceous plants, are also affected by Armillaria spp. (Ford et al. 2016; Grasso et al. 2000; Moore 1959; Robinson-Bax and Fox 2002; West et al. 2000). An extensive host list for Armillaria species was published prior to the determination that A. mellea in fact comprised several species (Raabe 1962). Since the publication of this text, there has been limited work to reveal the host range or preference of species with the genus Armillaria. Moore (1959) describes the genus to be "omnivorous" and presents a list of more than 100 British hosts. Greig and Strouts (1983) reported in an arboricultural leaflet that three tree species are completely incompatible hosts for Armillaria: box elder (Acer negundo), Californian black walnut (Juglans hindsii), and yew

${ }^{\dagger}$ Corresponding author. E-mail: jassydrakulic@rhs.org.uk

*The $\boldsymbol{e}$-Xtra logo stands for "electronic extra" and indicates that one supplementary table is published online.

Accepted for publication 2 July 2017.

This article is in the public domain and not copyrightable. It may be freely reprinted with customary crediting of the source. The American Phytopathological Society, 2017.
(Taxus baccata), alongside several other species and genera that were considered more resistant than most, based on records and observations not presented in the publication. While there is limited information available on the variability in resistance to infection of plants grown in U.K. gardens, this knowledge would be useful for gardeners in making planting choices.

The ecology of the species of Armillaria that are present in the U.K. has primarily been reported from woodland environments, with occasional records from garden locations (Gregory 1989; Rishbeth 1982). U.K. species recorded from surveys conducted between 1983 and 1989 were reviewed and summarized by Guillaumin et al. (1993), and comprised A. borealis (rare, present only in Scotland), A. cepistipes (less rare, prevalent in northern England and Scotland), A. ostoyae (widespread in both southern England and Scotland and rare in Wales), A. mellea (widespread in southern England, rare in Scotland), A. gallica (widespread in southern England, less common but present in Scotland, rare or absent in northern England and Wales), and A. tabescens (widespread in southeastern England). Five species of Armillaria were identified in an ancient broadleaved woodland in eastern England that was managed by regular coppicing: A. mellea and A. gallica most frequently, A. tabescens moderately frequently, plus A. cepistipes and A. ostoyae less frequently (Rishbeth 1991). In addition, A. ectypa has been found only occasionally in the U.K., in peat-bog environments (Jefferies 1999; Pérez-Sierra 2004).

Differences in pathogenicity have been observed between the different species (Gregory et al. 1991; Guillaumin et al. 1993). A. mellea and $A$. ostoyae are reported as the most virulent. The other species are secondary opportunistic pathogens, or merely saprotrophs, and it has been shown that the likelihood of Armillaria infection is strongly influenced by host vigor (Lee et al. 2016; Wargo and Harrington 1991). Weakly pathogenic species of Armillaria are considered important ecologically in undisturbed woodlands by selecting against weaker trees (Marçais and Bréda 2006). Less disturbance favors prolonged establishment of saprotrophic species, which may be able to deter more virulent species from being able to cause disease on healthy trees (Tsykun et al. 2012). The difference in virulence between the known pathogen A. mellea and the opportunist A. gallica was reduced or eliminated when Mediterranean oak trees were subjected to drought (Metaliaj et al. 2006). Thus, the relative virulence of species plus host health and garden condition, including level of disturbance, are among several other factors that would influence the likelihood of observing different Armillaria species on dead and dying garden plants.

It is thought that Armillaria species have differential host preferences, with A. ostoyae being associated primarily with conifer pathogenesis (Rishbeth 1982). In agreement, A. ostoyae was the most frequently identified species in Armillaria infection of Japanese conifers (Hasegawa 
et al. 2011), and was observed to be highly virulent in the majority of cases, although isolates with lower pathogenicity to conifers were observed in Europe. In Ukraine there was double the number of $A$. gallica and A. cepistipes rhizomorphs in beech forests compared with mixed conifer forests (Tsykun et al. 2012). Host preference was also observed in forests in Massachusetts, U.S.A., where a greater prevalence of A. mellea was found in white pine forests whereas A. gallica prevailed in hemlock forests (Brazee and Wick 2011). How informative such studies are to the likely host preference of garden trees to different Armillaria species is questionable, as diverse trees may be grown in the same location within one garden, restricting the potential transformation of rhizosphere conditions that would be encouraged if a tree species dominated an environment.

Denman et al. (2016) suggested a link between A. mellea and garden shrubs and broadleaves, as their sampling of U.K. oaks found instances where $A$. mellea infected plants in gardens, but not in woodland sites. This is in contrast to the work of several older studies that found A. mellea associated with wooded sites where Quercus spp. were present or had previously grown (Keča et al. 2009; Lushaj et al. 2010; Rizzo et al. 1998; Tsopelas 1999). However there is evidence that A. mellea is well suited to garden-like environments: it was the most common Armillaria species found in private gardens, vineyards, and orchards in Albania (Lushaj et al. 2010) and Greece (Tsopelas 1999). In Greece, A. mellea was also the most aggressive pathogen on such hosts, although in Albania A. tabescens was observed to cause the greatest disease severity. In both countries, A. gallica was commonly sampled, and considered to be growing either saprotrophically or as a weak pathogen in most cases. A. mellea has been documented as the causal agent of disease in many broadleaved trees in southern England, including apples and pears and in all cases where disease in gardens affected more than a single host plant $A$. mellea was found as the causal agent (Rishbeth 1982).

The RHS receives samples from its members for identification of disease, and between the years 2004 and 2007, the honey fungus obtained from these samples was differentiated at the species level. Data are presented to provide information on the host range and distribution of Armillaria species in U.K. gardens. Factors including the visibility or relative value of the plants affected would have an influence over the likelihood of a gardener to send in a diseased plant sample to the RHS. Despite these limitations, conclusions drawn from this study will provide horticulturists and gardeners with relevant data to inform management strategies, especially with regards to making informed planting choices.

\section{Materials and Methods}

Sampling. Samples were sent to the RHS from members making inquiries to request the identification of the causal agents of garden diseases.
Furthermore, all disease inquiries, including those only with written and pictorial evidence, are logged, and all that relate specifically to Armillaria are tagged. These data have been used to rationalize the data within the Armillaria species survey with the likelihood of a plant being reported to the RHS for any disease. Furthermore, a comparison was made between the hosts found to have the disease through the testing of sample material versus all hosts with inquiries on the topic of Armillaria infection.

Isolation. Samples comprising mushrooms, rhizomorphs, infected bark, and root material were dissected into roughly $1 \mathrm{~cm}^{3}$ pieces (or $1 \mathrm{~cm}$ lengths of rhizomorphs), taken from six representative parts of the specimen. The prepared portions were surface sterilized in diluted domestic bleach $(20 \% \mathrm{v} / \mathrm{v})$ and rinsed in sterile distilled water for $30 \mathrm{~s}$ each before being plated onto JJG media (1\% malt extract agar amended with $50 \mathrm{mg}$.liter ${ }^{-1}$ penicillin, $50 \mathrm{mg}$.liter ${ }^{-1}$ streptomycin sulfate, $25 \mathrm{mg}$.liter ${ }^{-1}$ polymyxin, and $1 \mathrm{mg}$ liter ${ }^{-1} 23 \%$ thiabendazole). After 3 days incubation in the dark at $23^{\circ} \mathrm{C}$, plates were assessed for Armillaria growth, which was then subcultured onto fresh JJG media. After 2 to 3 weeks, the isolates were then further subcultured onto carrot agar, which after 10 days were used to obtain pure cultures for direct PCR of the intergenic spacer region 1 (IGS) and via DNA extraction for PCR of the elongation factor-1 alpha (EF-1 $\alpha$ ).

Species identification. Molecular identification of species was conducted by PCR-RFLP (Harrington and Wingfield 1995; Pérez-Sierra et al. 1999). PCR was performed to amplify the IGS of the Armillaria genus, using primers listed in Table 1 . Per sample, $0.5 \mu \mathrm{M}$ of each of the forward and reverse primers and $23 \mu \mathrm{L}$ PCR water was added along with PuRe Taq Ready-to-go PCR beads (GE Healthcare). Hyphae were collected from agar plates with a sterile pipette tip and added to the reaction mixture and PCR beads that was stirred gently and then centrifuged briefly. Amplification was performed in a thermocycler (MWG) according to the following protocol: $95^{\circ} \mathrm{C}$ for $1 \mathrm{~min} 35 \mathrm{~s}, 35$ cycles of $95^{\circ} \mathrm{C}$ for $1 \mathrm{~min}, 60^{\circ} \mathrm{C}$ for $1 \mathrm{~min}, 72^{\circ} \mathrm{C}$ for $2 \mathrm{~min}$, and $72^{\circ} \mathrm{C}$ for $10 \mathrm{~min}$. PCR products $(3 \mu \mathrm{l})$ were run on a $1 \%$ Tris/Borate/EDTA (TBE) gel, and resultant bands of expected length (850 to $930 \mathrm{bp}$ ) excised cleaned up using a QIAquick PCR purification kit (QIAgen) and stored at $-80^{\circ} \mathrm{C}$ prior to RFLP digestion.

RFLP analysis was performed with $A l u \mathrm{I}$, whereby $2 \mu \mathrm{l}$ buffer, $1 \mu \mathrm{l}$ AluI (Promega), $7 \mu \mathrm{l}$ PCR water, and $10 \mu \mathrm{l}$ PCR product were combined and incubated at $37^{\circ} \mathrm{C}$ for $2 \mathrm{~h}$. Subsequently, two further digestions were performed using the PCR product, $B s m \mathrm{I}(\mathrm{Gibco})$ and $N d e \mathrm{I}$ (Promega). Digestions were incubated for $1 \mathrm{~h}$ at $37^{\circ} \mathrm{C}$ in the case of $N d e \mathrm{I}$ and $2 \mathrm{~h}$ at $65^{\circ} \mathrm{C}$ for $B s m \mathrm{I}$. Separation of digested bands was performed on a $2 \%$ TBE gel at $90 \mathrm{v}$ for $2 \mathrm{~h}$, along with a $100 \mathrm{bp}$ ladder, and visualized under UV light (BioRad Gel Doc 1000).

Species-specific primers that amplify EF-1 $\alpha$, published after the initial identifications had been performed (Mulholland et al. 2012), were later used to verify the identifications on a subset of the samples $(n=38)$.

Table 1. Primers used for the identification of Armillaria species

\begin{tabular}{|c|c|c|c|c|c|}
\hline Target & & Primer name & Primer sequence $\left(5^{\prime}-3^{\prime}\right)$ & Size (bp) & Reference \\
\hline & IGS & LR12R & CTGAACGCCTCTAAGTCAGAA & $\sim 860$ & Veldman et al., 1981 \\
\hline & & $\mathrm{O}-1$ & AGTCCTATGGCCGTGGAT & & Duchesne and Anderson 1990 \\
\hline \multirow[t]{16}{*}{$\mathrm{EF} 1-\alpha$} & Armillaria genus & ArmEF $1 \alpha$ FOR & GGAACTGGTGAGTTCGAAGCC & 488 & \\
\hline & & ArmEF $1 \alpha$ REV & AGACGGAGAGGCTTGTCGGAG & & \\
\hline & A. borealis (type $\mathrm{X}$ ) & ArmEF $1 \alpha$ FOR & GGAACTGGTGAGTTCGAAGCC & 371 & \\
\hline & & AborX-R358 & CATGCTAYAGAGGAYGTTAAGAACC & & \\
\hline & A. borealis (type $\mathrm{Y}$ ) & AborY-F100 & ACACCACTAAGGTACGAGATCTGCCG & 226 & \\
\hline & & AborY-R325 & GGTCATACTTGGGTAAGG & & \\
\hline & A. cepistipes & Acep-F140 & TTAGGCATATCTGACTGGTATC & 194 & Mulholland et al. 2012 \\
\hline & & Acep-R333 & AGCCCTRGTCATAGTTGG & & \\
\hline & A. gallica & Agal-F123 & YTGCTTTGCCTTKTGTTTAGCC & 220 & \\
\hline & & Agal-R342 & CGTTAAGRGRCACTGATCATA & & \\
\hline & A. mellea & Amel-F165 & TGGAGCGAGGACCGATT & 236 & \\
\hline & & Amel-R401 & GRCGACACCRGCCTTABTC & & \\
\hline & A. ostoyae & Aost-F102 & CCACCAAGGTACGAGATCTATCG & 240 & \\
\hline & & Aost-R341 & GTTAAGAGGCAGCACTGG & & \\
\hline & A. tabescens & Atab-F147 & GTTCGACATTTATCTTAGTGGAGTG & 329 & \\
\hline & & ArmEF $1 \alpha$ REV & AGACGGAGAGGCTTGTCGGAG & & \\
\hline
\end{tabular}


Ten isolates initially identified as A. ostoyae, 15 A. gallica, and $13 \mathrm{~A}$. mellea isolates were checked in this way, which confirmed the identities determined by RFLP. Cultures were grown on 1\% MEA for 6 to 8 weeks and DNA was extracted using a DNeasy extraction kit (Qiagen, Hilden, Germany). Reaction mixtures of $20 \mu$ l comprised BioMix Red mastermix (Bioline Reagents Ltd, U.K.), $0.5 \mathrm{nM}$ of each forward and reverse primer, and $1 \mu \mathrm{l}$ template DNA. For Armillaria species-specific assays, the thermocycling program used was as follows: $95^{\circ} \mathrm{C}$ for $5 \mathrm{~min}$, 35 cycles of $94^{\circ} \mathrm{C}$ for $30 \mathrm{~s}, 58^{\circ} \mathrm{C}$ for $30 \mathrm{~s}, 72^{\circ} \mathrm{C}$ for $1 \mathrm{~min}$, and $72^{\circ} \mathrm{C}$ for $7 \mathrm{~min}$. PCR products were run on $1.5 \% \mathrm{TBE}$ gels and visualized under UV light (BioRad Gel Doc 1000).

\section{Results}

A total of 638 samples were processed, which originated from 502 sites within the U.K. Of the samples with known plant hosts, there were 556 records for unique host genera from 457 different locations (i.e., multiple samples from one site taken from the same host genus and being infected with the same Armillaria species were counted only once per host genus), which are used to form the conclusions regarding the host preference for the different Armillaria species described below. Within this same set of 457 locations, there were 468 records for unique Armillaria species/site combinations, which can be used as a measure of geographical distribution. Of these 468 unique species/sites, $83.1 \%$ were $A$. mellea, $15.8 \%$ were $A$. gallica, and $1.1 \%$ were $A$. ostoyae (Fig. 1A).

Geographical distribution. Within the survey, there is a strong geographical bias toward areas around the RHS Garden at Wisley, with the vast majority of samples being sent from the same postcode area as the garden or in postcode areas immediately adjacent. The 10 best represented postcode areas were: Guildford $(n=65 ; 13.9 \%)$; Kingston-upon-Thames $(n=42 ; 9.0 \%)$; South West London \& Battersea $(n=24 ; 5.1 \%)$; Redhill $(n=17 ; 3.6 \%)$; Tonbridge $(n=15 ; 3.2 \%)$; Reading $(n=14 ; 3.0 \%)$; Slough $(n=14 ; 3.0 \%)$; Portsmouth $(n=12 ; 2.6 \%)$; Twickenham $(n=11 ; 2.4 \%)$; and West London \& Paddington $(n=11$; $2.4 \%$ ). Samples were sent from 83 postcode areas, which were almost entirely from England. Four samples were received from Wales, one from Scotland, and none from Northern Ireland. The mainland U.K. has been divided into five regions in order to compare the species distribution in each: northern, central, eastern, southwestern, and southeastern (Fig. 2).

A. mellea was found in 389 sites, from 78 postcode areas, and thus was absent only from four areas from which samples were received. A. gallica was found in 74 sites, from 34 postcode areas, including the most northern (Kilmarnock). A. ostoyae was only found in five sites, of the postcode areas Guildford, West \& Paddington, Carlisle, Redhill, and Slough (Fig. 3).

Biological diversity. Armillaria was isolated from multiple plant host species in 64 locations. The same pathogen species was found on multiple hosts in 56 sites, and in nine sites there was more than one Armillaria species present (including one instance of two species being found on the same host species). Of the 56 sites with a single species found on multiple hosts, $87.5 \%$ contained A. mellea, $9.7 \%$ A. gallica, and $1.8 \%$ A. ostoyae. In eight out of nine sites that contained more than one species of Armillaria, the combination of species was A. mellea and A. gallica. In the RHS Wisley site, A. mellea, A. gallica, and A. ostoyae were all identified.

Susceptible host plants. The top 10 genera from which Armillaria was successfully cultured and identified down to species level were Ligustrum (9.0\%), Viburnum (8.6\%), Prunus and Rosa (each 6.7\%), Rhododendron (4.3\%), Acer (3.4\%), Betula and Sorbus (each 2.7\%), Malus (2.5\%), and Cotoneaster (2.2\%). The best represented family was the Rosaceae (107 of 468 unique sites, representing 133 unique pathogen species/site combinations) (Fig. 1B). The species distribution within the Rosaceae was of a similar trend to that of all families combined, with $85.7 \%$ A. mellea, $11.3 \%$ A. gallica, and $3.0 \%$ for A. ostoyae. Hosts from the Rosaceae represented 15 genera, with the most common genera being Prunus and Rosa (each $25.5 \%$ of Rosaceae), Sorbus (10.6\%), Malus (9.9\%), Cotoneaster (8.5\%), and Photinia (5.7\%).
Detection of Armillaria in hosts was likely to be biased by popularity and value to the gardener (i.e., the likelihood to notice or to inquire about any observed disease) of plants in gardens, as well as the differing size of each family or genus. In order to highlight any host species that could have honey fungus infection either more or less frequently, the survey data were compared with the data obtained by the RHS across all inquiries to the pathology department. Of all pathology inquiries received in the years of the survey $(n=11,205), 9.8 \%$ were on the topic of honey fungus. Inquiries that concerned honey fungus that were linked to a specific host plant $(n=1,090)$ covered 141 host genera. The 10 most inquired about host plants from both the full set of pathology inquiries and from those specifically for Armillaria are presented in Table 2 .

From these datasets, some genera are represented in notably different abundance within the set of inquiries that specifically referenced Armillaria compared with those from all pathology-related inquiries (Table 3). Ligustrum was the host plant genus from which Armillaria was most frequently isolated, but was only the 12th most commonly inquired about host for all pathology inquiries, and inquiries specifically relating to Armillaria accounted for $44.4 \%$ of all Ligustrum inquiries $(n=180)$. Betula features as the equal seventh most frequently occurring Armillaria host but was the subject of only $0.8 \%$ of all pathology inquiries, ranking as the 29th most frequently inquired about host. Inquiries about Armillaria on Betula made up one third of all Betula inquiries $(n=90)$. Sorbus and Cotoneaster also feature in the top 10 hosts from which Armillaria was identified, but within all pathology inquiries each only represent the 19th and 32nd most commonly inquired about host plants, with the proportions of inquiries for these hosts that related to Armillaria being $24.8 \%$ (of 121 Sorbus inquiries) and $31.6 \%$ (of 76 Cotoneaster inquiries), respectively. For some host plants that were less commonly inquired about, the proportion of inquiries made about them which specifically related to Armillaria was noticeably high. Armillaria inquiries accounted for $50 \%$ of all inquiries about Hamamelis $(n=24)$, $46.7 \%$ of those on Fatsia $(n=15), 44.4 \%$ for Forsythia $(n=18)$, $36.7 \%$ for Escallonia $(n=30)$, and $35.6 \%$ for Cedrus $(n=45)$.

Resistant host plants. While the reporting of infected hosts indicates which ones are susceptible to the disease, the absence of reports of other hosts does not necessarily imply that these hosts are resistant,

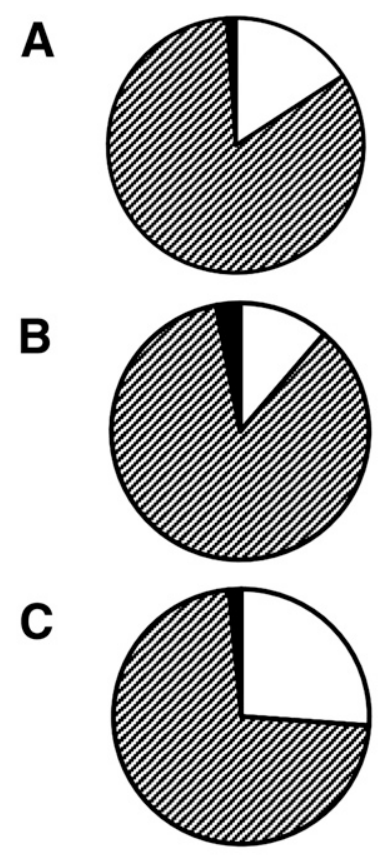

\section{$\square$ Armillaria gallica $\square$ A. mellea $\square$ A. ostoyae}

Fig. 1. Armillaria species composition for: A, all unique records; $\mathbf{B}$, the most commonly reported host family, the Rosaceae; and $\mathbf{C}$, the best represented postcode area, GU (Guildford). 
as other explanatory factors such as lack of popularity, visibility, or value to the gardener could likely also be involved. However, some differences can be seen between the host genera that members inquire about versus the frequency of finding Armillaria on these hosts. Genera that were commonly the subject of pathology inquiries but rarely on the topic of Armillaria include Buxus (4.2\% of all inquiries; $0.18 \%$ of Armillaria inquiries; Armillaria was not isolated from any Buxus specimens), Taxus (2.32\% of all inquiries; $0.28 \%$ of Armillaria inquiries; $0.36 \%$ of samples from which Armillaria was isolated), Solanum (2.18\%; $0.09 \% ; 0.18 \%)$, and to a lesser degree Pyrus $(2.81 \% ; 1.19 \%$; $0.72 \%$ ). Very few incidences of unique infections on conifers were identified (7.24\%). Of these, eight were $\times$ Cupressocyparis and six Cedrus, with no Pinus represented within the dataset at all.

Host range at RHS Wisley and the GU postcode area. RHS Garden Wisley was sampled 27 times, with samples taken from 18 distinct host genera from 16 different families. From two plant genera (Acer, Sapindaceae; Rhododendron, Ericaceae), two different Armillaria species were identified. A. mellea was identified from 10 genera, A. ostoyae from eight genera, and A. gallica from two genera. The Guildford postcode area (GU) had a greater proportion of unique records for A. gallica than in the survey overall (Fig. 1C).

Species-specific host preferences. All incidences of infection on Ligustrum were A. mellea $(n=46)$. In contrast, Viburnum $(n=47)$ had a similar ratio of incidences of A. gallica and A. mellea to the overall percentage incidences for each species, with $16.7 \% \mathrm{~A}$. gallica and $83.3 \%$ A. mellea. All three Armillaria species were isolated from Aesculus, Betula, Hamamelis, Prunus, Rhododendron, and Sorbus. Despite reports citing A. ostoyae as having a host preference for conifers (Blodgett and Worrall 1992; Greig and Strouts 1983), only one of the 11 hosts in this survey with A. ostoyae infection was a conifer (Larix).

Isolates without a plant host. Samples from 41 different sites were obtained from material that did not come directly from infected host tissues. Of these, the majority were A. gallica (70.7\%), followed by A. mellea (26.8\%), and there was just a single instance of A. ostoyae $(2.0 \%)$. Within this set of samples, A. gallica $(n=29)$ was isolated most commonly from rhizomorphs $(75.9 \%)$, whereas $A$. mellea and A. ostoyae were entirely represented by mushrooms.

Newly reported hosts. As discussed below, there are 14 genera that have not been previously recorded in the scientific literature as

Table 2. Host genera most commonly inquired about for all requests, and specifically for inquiries related to Armillaria for the survey period (2004 to 2007)

\begin{tabular}{lllllll}
\hline \multicolumn{3}{c}{ All pathology inquiries } & & \multicolumn{3}{c}{ Armillaria inquiries } \\
\cline { 1 - 1 } Rank & Genus & \% & & Rank & \multicolumn{1}{c}{ Genus } & \% \\
\hline 1 & Prunus & 8.73 & & 1 & Viburnum & 7.71 \\
2 & Malus & 4.45 & & 2 & Ligustrum & 7.34 \\
3 & Rhododendron & 4.39 & & 3 & Prunus & 6.42 \\
4 & Buxus & 4.20 & & 4 & Rhododendron & 5.32 \\
5 & Rosa & 3.22 & & 5 & Rosa & 5.23 \\
6 & Pyrus & 2.81 & & 6 & Malus & 4.31 \\
7 & Acer & 2.77 & & 7 & Acer & 3.39 \\
8 & Viburnum & 2.61 & & $8=$ & Betula & 2.75 \\
9 & Taxus & 2.32 & & $8=$ & Salix & 2.75 \\
10 & Solanum & 2.18 & & $8=$ & Sorbus & 2.75 \\
\hline
\end{tabular}

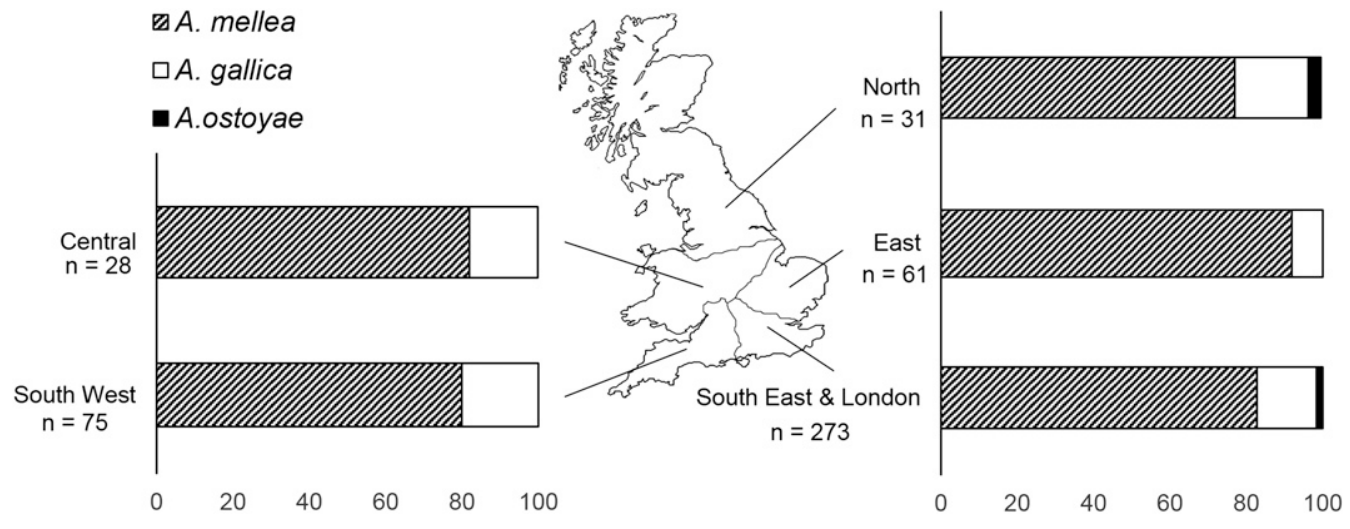

Fig. 2. Species distribution of Armillaria in U.K. gardens according to geographic region.
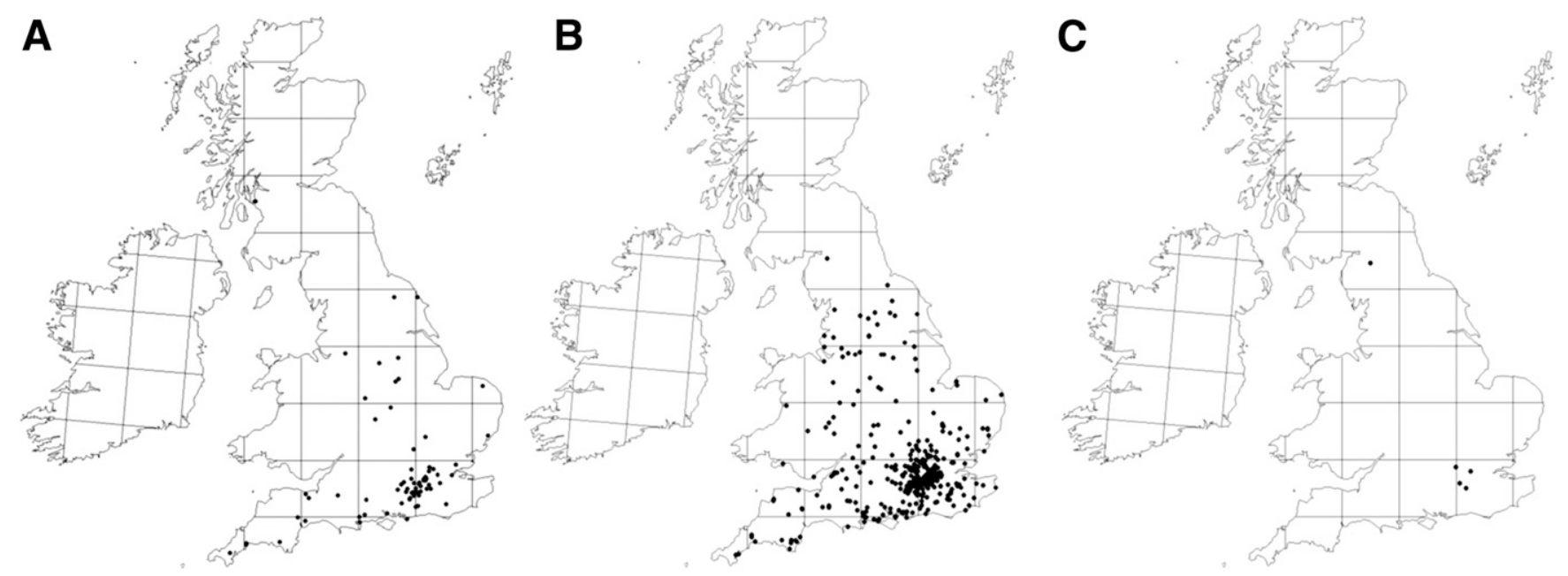

Fig. 3. Incidence of Armillaria species in U.K. gardens: A, A. gallica; B, A. mellea; and C, A. ostoyae. 
hosts of Armillaria: Akebia, Bombax, Brachyglottis, Chamaerops, Cordyline, Cotinus, Exochorda, Hamamelis, Linnaea, Mercurialis, Mimosa, Penstemon, Skimmia, and Stachyurus.

\section{Discussion}

The main finding of this survey is the dominance of $A$. mellea as the primary causal agent of Armillaria root rot in garden locations in the U.K. Previous studies indicated a prevalence of this species in more disturbed sites (Guillaumin et al. 1993). In the small number of cases in English gardens studied previously (Rishbeth 1982), infections that had reached more than one type of plant host were all caused by A. mellea. This trend was still true in the presented survey, despite the far larger number of sites included: A. mellea was the only species found in $87.5 \%$ gardens in which more than one plant host type was affected, showing a greater prevalence in these situations than its overall abundance. This work therefore supports the hypothesis that the majority of garden disease caused by Armillaria is due to A. mellea infection, and in such cases the pathogen is at risk of spreading to multiple hosts within the site.

The second most prevalent species was A. gallica, which was the cause of a greater proportion of the infections in gardens where only a single host species was sampled compared with sites where multiple host species occurred. All samples of rhizomorphs received were identified as A. gallica. These observations are consistent with the growth habits described for A. gallica in woodlands and forests, whereby the fungus survives in the soil as a network of rhizomorphs connected to subterranean woody substrates, acting as a pathogen only opportunistically on hosts that have been otherwise weakened (Fox 2000; Kile et al. 1991). The conclusion that the same growth habit is exhibited in gardens is further supported by the work of Rishbeth (1982), which reported that A. gallica was found on host material from gardens in which only single trees had been killed, in contrast to sites with deaths of multiple hosts where A. mellea was found in every case. Sites were sampled in the present study by members seeking information regarding problems observed within their gardens. There was no obligation to send in samples from all affected hosts, so it remains possible that other hosts were affected but not reported.

Surveys of woodland sites in the 1980s showed incidence of A. gallica in northern latitudes (Guillaumin et al. 1993), especially within Scotland. Results from this survey demonstrate its presence within northern England as well, and that in the north A. gallica isolates comprised a greater proportion of infections (18\%) than in any other region (Fig. 2), potentially indicating an increase in the prevalence of A. gallica in northern areas.

That A. mellea is still commonly found in southern England is consistent with previous findings, but that this species was present in $75 \%$ and $88.8 \%$ of sites in the northern and central regions, respectively, suggests that the prevalence of this species may have increased in the last 20 years. This conclusion should be taken with caution, as for a sample to be sent the host plant would have to be showing signs of ill-health, which in itself is likely to lead to an over-representation of more pathogenic Armillaria species. A. ostoyae was found to be in a pattern consistent with previous studies from woodlands, with occurrence in southern England and Scotland: four out of five locations in this study were from the south and one was from very northern England (Carlisle). It is also noteworthy that no instances of A. tabescens were identified in this study, and it may be that this species is not present in gardens, or that the prevalence of this species has diminished.

Denman et al. (2016) reported that $A$. gallica was the most commonly identified species found in oak trees sampled from woodlands, with $A$. mellea being found in a minority of cases but those cases were only in two garden environments. Two other species, A. ostoyae and A. tabescens, were found infrequently on oaks. Previous studies showed that A. tabescens is common in southeastern England (Guillaumin et al. 1993), and thus the low frequency of A. tabescens found by Denman et al. (2016) is unexpected, raising further questions about changes in the distribution and host preferences of Armillaria species over time.

Occurrence of more than one species of Armillaria in one garden was recorded in a handful of cases within this survey, with the most common combination of species being A. mellea and A. gallica. In one case within this survey, these two Armillaria species were isolated from the same host plant ( $\times$ Cupressocyparis leylandii). The frequency of occurrence was low in this survey, but in the majority of cases only a single sample was sent in per garden, and thus these data are not able to inform us as to whether coincidence of species in gardens is more common in reality. The implications of having competing species in a garden is an interesting area to consider and one which would be valuable for further research. If less virulent species of Armillaria are able to occupy the same niche as more aggressive species, they may be able to exclude incoming pathogenic species. Provided that there is the potential to make a more favorable environment for weaker pathogens, this could lead to repression of disease-causing species by reducing their ability to invade a garden.

For the gardener, pruning is an important management tool, although this practice appears to lead to increased susceptibility for hosts in contracting pathogenic infection by the otherwise saprotrophic $A$. gallica. Heavy pruning was the only source of host weakening observed in gardens which featured A. gallica infection (Rishbeth 1982). As such, a presiding infection of A. gallica in a garden may be beneficial in terms of saprotrophic activity and potential exclusion of more virulent species, but gardeners ought to beware of stressing plants unnecessarily with excessive pruning.

A. mellea prevalence has been shown to be related to the abundance of the most susceptible types of trees in mixed mountain forests in the central U.S.A. (Bruhn et al. 2000). In mixed hardwood forests in California, the most abundant trees were also the most likely to be infected (Baumgartner and Rizzo 2001), implying that adaptation to the host can occur within a genet, which in turn makes the isolate better able to colonize all trees of that type within reach. Data were not collected on the host plant diversity in the gardens

Table 3. Levels of resistance/susceptibility to Armillaria as indicated by under/over representation in the most common host genera. Data from RHS advisory service datasets.

\begin{tabular}{|c|c|c|c|c|c|c|c|}
\hline \multirow[b]{2}{*}{ Genus } & \multicolumn{2}{|c|}{$\begin{array}{c}\text { Armillaria } \text { species } \\
\text { identification survey }\end{array}$} & \multicolumn{2}{|c|}{ Armillaria inquiries } & \multicolumn{2}{|c|}{$\begin{array}{l}\text { All pathology } \\
\text { inquiries }\end{array}$} & \multirow{2}{*}{$\begin{array}{l}\text { Ratio of Armillaria inquiries } \\
\text { to all pathology inquiries }\end{array}$} \\
\hline & Rank & $\%$ & Rank & $\%$ & $\overline{\text { Rank }}$ & $\%$ & \\
\hline Ligustrum & 1 & 8.99 & 2 & 7.34 & 12 & 1.61 & 0.44 \\
\hline Viburnum & 2 & 8.63 & 1 & 7.71 & 8 & 2.61 & 0.28 \\
\hline Prunus & $3=$ & 6.47 & 3 & 6.42 & 1 & 8.73 & 0.07 \\
\hline Rosa & $3=$ & 6.47 & 5 & 5.23 & 5 & 3.22 & 0.16 \\
\hline Rhododendron & 5 & 4.32 & 4 & 5.32 & 3 & 4.39 & 0.12 \\
\hline Acer & 6 & 3.42 & 7 & 3.39 & 7 & 2.77 & 0.12 \\
\hline Betula & $7=$ & 2.70 & $8=$ & 2.75 & 29 & 0.80 & 0.33 \\
\hline Sorbus & $7=$ & 2.70 & $8=$ & 2.75 & 19 & 1.08 & 0.25 \\
\hline Malus & 9 & 2.52 & 6 & 4.31 & 2 & 4.45 & 0.09 \\
\hline Cotoneaster & 10 & 2.16 & 12 & 2.20 & 32 & 0.68 & 0.32 \\
\hline
\end{tabular}


from which samples were obtained in the present study. However, an interesting area for future research would be to consider the planting abundance and pattern of more and less resistant plants within a garden alongside the species of Armillaria that colonize them. The impact that host selection has on the co-occurrence of Armillaria is also relevant, and it would be of interest to explore the potential for encouragement of less pathogenic Armillaria species.

A comparison of the host plants listed within this survey with those cited as being resistant (Greig and Strouts 1983) shows great similarity, with a few notable exceptions. In corroboration with the previous study, this survey found no instances of disease in Ailanthus altissima, Arundinaria and other bamboos, Buxus sempervirens, Calocedrus decurrens, Clematis spp., Hedera helix, Mahonia spp., Pseudotsuga menziesii, Robinia pseudoacacia, Sambucus nigra, Tamarix spp., or Tilia spp., all of which were listed in Greig and Strouts (1983) as resistant to Armillaria infection. In several cases, the genus was listed in the survey without details of the species. This means that for Acer negundo or Juglans hindsii, reported as virtually immune to Armillaria infection (Greig and Strouts 1983), it is not known if any incidences of disease were observed, as neither was recorded specifically, even though the disease was recorded in the present study at the genus level. A third species, Taxus baccata, was described as incompatible to Armillaria by these authors but occurred in this survey in two sites in England, as well as one sample received from Belgium (excluded from the survey data presented). Other hosts that were found in this survey despite being reported to be highly resistant by these previous authors include Elaeagnus $(n=4)$, Fagus $(n=6)$, Fraxinus $(n=3)$, Ilex $(n=9)$, Quercus $(n=$ $4)$, and Prunus laurocerasus $(n=4)$. In contrast, the monkey puzzle Araucaria was listed as being highly susceptible yet was only featured once in the survey. This is even more surprising as this is a very visible garden plant that is commonly grown by U.K. gardeners, and thus these survey data cast doubt over the level of susceptibility of modern varieties.

This work has revealed new insights into the epidemiology of Armillaria within garden environments in the U.K. The impact of these findings for gardeners touch upon the best approach to control the disease and planting choices. Firstly, if multiple plants are affected by Armillaria root rot within a garden, infection by the most pathogenic species, A. mellea, should be assumed and action taken to limit the spread of infection via removal and destruction of infected host material and associated soil. If infection is limited to a single host species, especially old or weakened individuals, the likely causal species is A. gallica. In such cases, drastic action is unlikely to be required and toleration of the pathogen may be acceptable so long as good host vigor is maintained for the rest of the plants in the garden. Secondly, in terms of planting choices, privet hedges are particularly susceptible to Armillaria root rot and infections ought to be dealt with as soon as they are identified to prevent losing entire hedgerows.

Several new ornamental hosts have been identified in this study (including the popular garden plants witch hazel, Hamamelis, and smoketree, Cotinus), expanding upon the already vast host range (Aguin et al. 2008; Moore 1959; Raabe 1962, 1979; Smith and Kile 1981; Thanassoulopoulos and Artopeadis 1991; Tsopelas 1999) that A. mellea is capable of colonizing. More work is needed to verify other potentially resistant hosts since this work cannot distinguish true resistance from under-reporting. While there was corroboration in the data presented for several hosts previously reported as resistant to Armillaria root rot, it appears that pathogenicity toward Taxus has increased and, even though the relative importance of this disease for yew is lower than for many hosts, it should not be described as highly resistant to Armillaria. Furthermore, herbaceous hosts ought to be respected as substrates that can facilitate the spread of $A$. mellea between woody hosts, and removed as any other host in an infected bed if attempting eradication of the fungus in a garden.

\section{Acknowledgments}

We thank I. Waghorn for technical support and assistance in figure preparation, J. Denton for technical laboratory assistance, and RHS members for the provision of sample material. The Royal Horticultural Society (RHS) is a registered charity, no. $222879 / \mathrm{SC} 038262$.

\section{Literature Cited}

Aguin, O., Escofet, P., Sainz, M. J., and Mansilla, J. P. 2008. Especies del genero Armillaria identificadas en plantas lenosas ornamentals en Galicia. Actas de Horticultura no. 52. Innovacion y future en la jardineria. Simposio Iberoamericano IV Jornadas Ibericas de Horticultura Ornamental. Pontevedra, Espana.

Baumgartner, K., and Rizzo, D. M. 2001. Ecology of Armillaria spp. in mixedhardwood forests of California. Plant Dis. 85:947-951.

Blodgett, J. T., and Worrall, J. J. 1992. Distributions and hosts of Armillaria species in New York. Plant Dis. 76:166-170.

Brazee, N. J., and Wick, R. L. 2011. Armillaria species distribution and site relationships in Pinus- and Tsuga- dominated forests in Massachusetts. Can. J. For. Res. 41:1477-1490.

Bruhn, J. N., Wetteroff, J. J., Jr., Mihail, J. D., Kabrick, J. M., and Pickens, J. B. 2000. Distribution of Armillaria species in upland Ozark Mountain forests with respect to site, overstory species composition and oak decline. Eur. J. Forest Pathol. 30:43-60.

Denman, S., Barrett, G., Kirk, S. A., McDonald, J. E., and Coetzee, M. P. A. 2016. Identification of Armillaria species on declined oak in Britain: implications for oak health. Forestry 90:148-161.

Duchesne, L. C., and Anderson, J. B. 1990. Location and direction of transcription of the 5S rDNA gene in Armillaria. Mycol. Res. 94:266-269.

Ford, K. L., Henricot, B., Baumgartner, K., Bailey, A. M., and Foster, G. D. 2016 A faster inoculation assay for Armillaria using herbaceous plants. J. Hortic. Sci. Biotechnol. 92:39-47.

Fox, R. T. V. 2000. The extent of losses and aims for managing Armillaria. Pages 139-149 in: Armillaria Root Rot: Biology and Control of Honey Fungus. R. T. V. Fox, ed. Intercept Ltd, Hampshire, U.K.

Grasso, S., Pane, A., and Cacciola, S. O. 2000. First report of Armillaria mellea on a fern from Italy. Plant Dis. 84:592.

Gregory, S. C. 1989. Armillaria species in northern Britain. Plant Pathol. 38:93-97.

Gregory, S. C., Rishbeth, J., and Shaw, C. G., III. 1991. Pathogenicity and virulence. Pages 76-87 in: Armillaria Root Disease Agriculture Handbook No. 691. C. G. Shaw III and G. S. Kile, eds. United States Department of Agriculture Forest Service, Washington, DC.

Greig, B. J. W., and Strouts, R. G. 1983. Arboricultural leaflet 2: Honey Fungus. Forestry Commission, Department of the Environment, London.

Guillaumin, J. -J., Mohammed, C., Anselmi, N., Courtecuisse, R., Gregory, S. C. Holdenrieder, O., Intini, M., Lung, B., Marxmüller, H., Morrison, D., Rishbeth J, Termoshuizen, A. J., Tirró, A., and van Dam, B. 1993. Geographical distribution and ecology of the Armillaria species in western Europe. Eur. J. Forest Pathol. 23:321-341.

Harrington, T. C., and Wingfield, B. D. 1995. A PCR-based identification method for species of Armillaria. Mycologia 87:280-288.

Hasegawa, E., Ota, T. H., Sahashi, N., and Kikuchi, T. 2011. Ecology of Armilllaria species on conifers in Japan. For. Pathol. 41:429-437.

Jefferies, K. 1999. New British Records: record 156 Armillaria ectypa. Mycologist 13:19-22.

Keča, N., Karadzic, D., and Woodward, S. 2009. Ecology of Armillaria species in managed forests and plantations in Serbia. For. Pathol. 39:217-231.

Kile, G. A., McDonald, G. I., and Byler, J. W. 1991. Ecology and disease in natural forests. Pages 102-121 in: Armillaria Root Disease Agriculture Handbook No. 691. C. G. Shaw III and G. S. Kile, eds. United States Department of Agriculture Forest Service, Washington, DC.

Lee, C. A., Dey, D. C., and Muzika, R. 2016. Oak stump-sprout vigor and Armillaria infection after clearcutting in southeastern Missouri, USA. For. Ecol. Manage. 374:211-219.

Lushaj, B. M., Woodward, S., Keca, N., and Intini, M. 2010. Distribution, ecology and host range of Armillaria species in Albania. For. Pathol. 40 485-499.

Marçais, B., and Bréda, N. 2006. Role of an opportunistic pathogen in the decline of stressed oak trees. J. Ecol. 94:1214-1223.

Metaliaj, R., Sicoli, G., and Luisui, N. 2006. Pathogenicity of Armillaria isolates inoculated on five Quercus species at different watering regimes. Phytopathol. Mediterr. 45:3-9.

Moore, W. C. 1959. Pages 57-61 in: British Parasitic Fungi. Cambridge University Press, U.K.

Mulholland, V., MacAskill, G. A., Laue, B. E., Steele, H., Kenyon, D., and Green, S. 2012. Development and verification of a diagnostic assay based on EF-1 a for the identification of Armillaria species in Northern Europe. For. Pathol. 42:229-238.

Pérez-Sierra, A. 2004. Armillaria ectypa (Fr.) Lamoure in the U.K. Systematics, diagnostics and epidemiology of the fungal genus Armillaria. $\mathrm{PhD}$ thesis, Chapter 4. Birkbeck College, University of London.

Pérez-Sierra, A., Whitehead, D., and Whitehead, M. 1999. Investigation of a PCRbased method for the routine identification of British Armillaria species. Mycol. Res. 103:1631-1636.

Raabe, R. D. 1962. Host list of the root rot fungus, Armillaria mellea. Hilgardia 33: 25-88.

Raabe, R. D. 1979. Some previously unreported hosts of Armillaria mellea in California, III. Plant Dis. Rep. 63:494-495. 
Rishbeth, J. 1982. Species of Armillaria in Southern England. Plant Pathol. 31:9-17. Rishbeth, J. 1991. Armillaria in an ancient broadleaved woodland. For. Pathol. 21:239-249.

Rizzo, D. M., Whiting, E. C., and Elkins, R. B. 1998. Spatial distribution of Armillaria mellea in pear orchards. Plant Dis. 82:1226-1231.

Robinson-Bax, C., and Fox, R. T. V. 2002. Root rots of herbaceous plants caused by Armillaria mellea. Mycologist 16:21-22.

Smith, L., and Kile, G. A. 1981. Distribution and hosts of Armillaria root rot in Melbourne suburban gardens. Australas. Plant Pathol. 10:41-42.

Thanassoulopoulos, C. C., and Artopeadis, M. C. 1991. Some previously unreported hosts of Armillaria root rot. Plant Dis. 75:101.

Tsopelas, P. 1999. Distribution and ecology of Armillaria species in Greece. Eur. J. Forest Pathol. 29:103-116.
Tsykun, T., Rigling, D., Nikolaychuk, V., and Prospero, S. 2012. Diversity and ecology of Armillaria species in virgin forests in the Ukrainian Carpathians. Mycol. Prog. 11:403-414

Veldman, G. M., Klootwijk, J., de Regt, V. C. D. H., Planta, R. J., Branlant, C. Krol, A., and Ebel, J.-P. 1981. The primary and secondary structure of yeast 26S rRNA. Nucleic Acids Res. 9:6935-6952.

Wargo, P. M., and Harrington, T. C. 1991. Host stress and susceptibility. Pages 88-101 in: Armillaria Root Disease Agriculture Handbook No. 691. C. G Shaw III and G. S. Kile, eds. United States Department of Agriculture Forest Service, Washington, DC.

West, J. S., Hughes, C., and Fox, R. T. V. 2000. Armillaria mellea can infect the perennial weed, Rumex obtusifolius, in the U.K. Plant Pathol. 49:808. 